$7^{\circ}$ Simposio Internacional de Investigación Multidisciplinaria / Ciencia y Tecnología 7th Internationalm Symposium on Multidisciplinary Research / Sciences and Technology

\title{
CT-01 Áreas vulnerables ante fenómenos naturales, microcuenca rio Peshjá, La Unión, Zacapa
}

Vulnerable areas to natural phenomena, microbasin of Peshjá River, La Union, Zacapa

\author{
Antonio Casasola
}

Centro Universitario de Zacapa, Universidad de San Carlos de Guatemala, Guatemala

*Autor al que se dirige la correspondencia: antoniiocs82@gmail.com

\section{Resumen}

$\mathrm{E}$ ste estudio se realizó como una contribución al análisis que contribuya a identificar las áreas vulnerables ante fenómenos naturales de la microcuenca rio Peshjá, del municipio de La Unión, Zacapa. El estudio de las cuencas hidrográficas del municipio de La Unión, Zacapa, debido a su ubicación en el departamento, en las áreas altas, se ve expuesta a fenómenos hidrológicos extremos. La importancia de la planificación del uso de los suelos, tanto para su uso agrícola, de hábitat, como de la protección de áreas vulnerables a desastres, es de mucha importancia debido a la gran cantidad de precipitación que reciben. Se recabó la información necesaria que generó los datos suficientes de precipitaciones, datos proporcionados por la estación meteorológica del municipio; de texturas, tipos de suelos, cobertura vegetal y forestal, se obtuvieron por medio de muestreos en el campo con GPS, chuzos y bolsas ziploc, las que se trasladaron al laboratorio del Centro Universitario de Oriente y así se identificaron los tipos de texturas; con el programa ArcGis se utilizó la metodología de ponderación de variables, con lo que se concluyó el análisis georeferencial en las distintas áreas de la microcuenca, y se evaluaron los distintos niveles de vulnerabilidad ante fenómenos naturales.

Palabras claves: Análisis hidrológico, análisis georreferencial

\begin{abstract}
$T_{1}$ his study was made as a contribution to the analysis that helps to identify areas with vulnerability to natural phenomena in the microbasin of the Peshjá River of the township of La Unión, Zacapa. The study of the watersheds of the township of La Union, Zacapa faces extreme hydrological phenomena due to its location in the department, in the high areas. It is crucial the land use planning, both for agricultural use, of habitat; and protection of vulnerable areas to disasters, because of the large amount of rainfall they receive. It was collected the necessary information to find satisfactory rainfall data, that was given by the weather station of the township; of textures, soil types, vegetation and forest cover, they were obtained through field sampling with GPS, chuzos and ziploc bags, which were transferred to the laboratory of the Centro Universitario de Oriente to identify the types of textures. It was used the methodology of weighting of variables with the ArcGis program, with which the georeferenced analysis was concluded in the different areas of the microbasin, and the different levels of vulnerability to natural phenomena were evaluated.
\end{abstract}

Keywords: Hydrological phenomena, georeferential analysis 